\title{
Inertización y valorización de polvos de lijado de barnices procedentes de residuos de la industria de la madera
}

\section{Encapsulation and re-use of wood industry waste: varnish powder}

\author{
$\underline{\text { I. Oteiza }}^{(*)}$, F. Hernández-Olivares ${ }^{(* *)}$ y A. Acosta ${ }^{(* * *)}$
}

\section{RESUMEN}

En este artículo se presentan los resultados obtenidos, en una primera etapa, del estudio del material que denominaremos como xiloarcilla, compuesto por arcilla y por un subproducto de las industrias de la madera, que en este caso son los polvos del lijado y del barnizado y excedentes de estos productos utilizados en el acabado de muchos componentes de madera (PLB), estos polvos se adicionaron a la arcilla en cantidades entre el $1 \%$ y el $5 \%$ del peso total del compuesto. Se realizó un estudio de caracterización de los materiales aislados y posteriormente del compuesto xiloarcilla, con énfasis en el comportamiento físico-mecánico y su respuesta química y medioambiental, como material de construcción.

Palabras clave: valorización de residuos, madera, polvo de barnices, arcillas, ladrillos cerámicos.

\section{SUMMARY}

The present article describes the findings of the first stage of the analysis of xiloarcilla, a material made of clay and a wood industry by-product, namely the wood and polyurethane varnish powder pump-suctioned off wood components during sanding and polishing. This powder was added to the clay in proportions of from $1 \%$ to $5 \%$ by weight. The prime materials as well as the xiloarcilla compound were characterized, in the latter case primarily to determine its physical-mechanical properties and chemical and environmental feasibility as a construction material.

Keywords: waste re-use, wood, varnish dust, clay, clay brick.

\section{INTRODUCCIÓN}

El estudio surge en el Centro Tecnológico de la Madera de Toledo (CTM), a través del proyecto de investigación, titulado "Xiloarcilla 02" (1), cuyo objetivo principal es la valorización de los residuos de las industrias de la madera de

\section{INTRODUCTION}

The study was conducted in the Wood Technology Centre (Spanish initials, CTM) at Toledo as part of a research project titled "Xiloarcilla 02" (1), whose chief objective is the re-use of waste from the Castilla-La Mancha wood

(*) Instituto Ciencias de la Construcción Eduardo Torroja - CSIC, Madrid (España).

(**) Departamento de Construcción y Tecnología Arquitectónicas, ETS Arquitectura, Universidad Politécnica de Madrid.

$(* * *)$ Facultad de Ciencias Químicas. Universidad de Castilla-La Mancha, Ciudad Real (España). 
Castilla-La Mancha asociados a la fabricación de productos cerámicos de construcción, en la misma región.

Existe una extensa experiencia e interés creciente en la utilización de residuos y subproductos de la madera para la fabricación de nuevos materiales de construcción (2). Sin embargo, no hay referencias destacables sobre la valorización de residuos de los barnices y lacados producidos por la industria de la madera. Es conocido que algunos residuos de la industria de la madera y derivados son difícilmente valorizables, por ello, se planteó la posibilidad de adicionarlos a las pastas cerámicas. El objetivo inicial fue la búsqueda de procedimientos de inertización primero y valorización después, si era posible, de los residuos peligrosos y, en algunos casos, tóxicos (RTP), generados por la industria de la madera. De entre todos los RTP se seleccionó el de menor contenido agresivo y de más facilidad de manipulación por el personal del CTM, para una primera exploración. Resultó ser el polvo de lijado de barnices, por lo general poliuretanos contaminados con partículas de madera del lijado. La propuesta de mezclarlos con arcilla tenía la finalidad de fijar a la nueva estructura molecular de la arcilla cocida los componentes químicos de mayor riesgo y potencial toxicidad. Debía verificarse posteriormente, por lixiviación, que la arcilla cocida había incorporado establemente estos posibles compuestos y que tampoco en la emisión de humos se contenían dioxinas $\mathrm{u}$ otros componentes contaminantes. De manera secundaria se aprovechaba el calor de combustión de estos productos para ahorrar energía en la cocción de las arcillas, lo que podría sugerir su uso para fabricar productos cerámicos útiles en construcción.

El trabajo realizado se ha centrado en el desarrollo de una investigación experimental en modelos reducidos de material xiloarcilla (mezcla de arcilla con residuos de la industria de la madera), comparando los resultados con el material patrón de arcilla sin adiciones.

En la región de Castilla-La Mancha, se produce el 25 por ciento del total de la producción española de arcilla cocida (3), existiendo una concentración de empresas transformadoras de las arcillas en la región de La Sagra de la provincia de Toledo, esto es gracias a que se cuenta con una excelente y abundante materia prima para la fabricación de productos cerámicos utilizados en la construcción, tales como ladrillos de diferentes tipos para exteriores e interiores, bovedillas, tejas y bloques de arcilla con prestaciones aislantes especiales.

Las arcillas utilizadas en la investigación son las más comunes en las industrias cerámicas de la región de La Sagra y el material empleado como adición a la arcilla es el polvo proveniente del lijado de productos barnizados (PLB), clasificado como residuo peligroso (RP) y de difícil gestión, eliminación y valorización. industry as a prime material in regional plants manufacturing clay brick and similar construction products.

A fair amount of experience has been acquired (2) in the use of wood industry waste and by-products in the manufacture of new building materials, an area of growing interest. And yet there are no relevant references to the re-use of varnish and lacquer waste generated by the wood and furniture industry. The possibility of adding certain types of wood waste and residue, known to be scantly re-usable, to clay paste was explored in this study. The initial objective was to seek encapsulation procedures and possible uses for the hazardous and in some cases toxic waste (HTW) generated by the wood industry. The least aggressive type of HTW and the type that could be most readily handled by CTM staff was chosen for initial exploration: i.e., varnish powder, generally consisting in polyurethane with wood powder impurities. The purpose of mixing this powder with clay was to fix the most hazardous and potentially toxic chemical components in the new molecular structure formed during firing. Leaching tests were then run to verify whether the fired clay had stably incorporated these compounds, while the fumes were analyzed to ensure that no dioxins or other pollutants were emitted. A secondary aim was to capitalize on these products' heat of combustion to save energy in the clay firing process, with a view to their use in the manufacture of clay brick and similar construction materials.

Experimental research was conducted on small samples of xiloarcilla (clay-wood industry waste mix), comparing the results with clay products containing no additions used as a control.

Twenty five per cent of all Spanish fired clay is produced in the Castilla-La Mancha region (3). A number of clay processing plants is clustered in the La Sagra area in the province of Toledo, where there is an abundant supply of excellent prime materials for making clay-based construction materials such as different types of brick for interiors and exteriors, pan forms, roof tiles or clay block with special insulation properties.

The clays used for this study were the types most commonly employed in the La Sagra, Toledo region, while the material added to the clay was powder from varnished wood (VP), a by-product regarded to constitute hazardous waste (HW) not readily managed, eliminated or re-used. 


\section{MATERIALES}

El compuesto xiloarcilla, objeto de este estudio, se elabora fundamentalmente con dos materiales, por un lado, los PLB y, por otro lado, la arcilla utilizada para la elaboración de productos cerámicos para la construcción. Los materiales que componen la xiloarcilla se analizaron de forma separada. En cuanto a la caracterización de las arcillas, los valores característicos fueron suministrados por AITEMIN (4).

\subsection{Los polvos de lijado de barnices (PLB) como residuo valorizable}

Aunque la industria de la madera no está considerada como una de las industrias de mayor producción de residuos tóxicos y peligrosos, como ocurre con otras tales como la industria química, la de fabricación de automóviles o la de productos metálicos, sin embargo, está catalogada como productora de residuos tóxicos y peligrosos por algunos productos fundamentalmente del sector de acabados, como son los barnices y, por lo tanto, éstos deben ser gestionados adecuadamente de acuerdo con las normativas de medio ambiente (5).

Para este primer estudio, se optó por utilizar y analizar los residuos que se obtienen del lijado de los productos barnizados; son polvos muy finos que permiten mezclarse con la arcilla húmeda, lo que en principio requiere de un tratamiento previo antes de su mezcla.

Los productos que se utilizan para dar el acabado final de los componentes de construcción en madera (6) tales como puertas, muebles, estructuras, etc., como barnices en la industria de la madera, pueden tener diferentes composiciones químicas, destacando los de base de poliuretanos, tanto en los barnices de fondo (casi el $90 \%$ de los productos utilizados contienen poliuretano), como en los barnices de acabado (que llegan al $50 \%$ de los productos).

Como hipótesis inicial, en cuanto a la adición de los PLB a las mezclas de arcilla, se planteó el poder eliminar de manera permanente estos residuos potencialmente contaminantes y de difícil gestión y valorización. Al introducirlos en la masa de arcilla y cocida ésta, se consigue que los humos sean filtrados por la propia arcilla y se depuren los compuestos volátiles contaminantes, emitiendo a la atmósfera sólo aquellos gases inertes en proporciones inferiores a los límites que establece la normativa vigente. Los residuos sólidos del PLB quedan fijados de tal manera a la estructura molecular del compuesto que será imposible su reenvío al medio ambiente por lixiviación o descomposición.

La adición de materiales orgánicos a las pastas de arciIla, procedentes de subproductos agrícolas (orujo, huesos de aceitunas) y de la madera (serrín, celulosas de la

\section{MATERIALS}

Xiloarcilla, the compound analyzed in this study, is made from essentially two materials, VP and the clay used to manufacture clay-brick and similar construction products. The xiloarcilla components are analyzed separately hereunder. The values used for the clay were furnished by AITEMIN (4).

\subsection{Varnish powder (VP) as re-usable waste}

Although the wood industry, unlike the chemicals, automobile manufacturing or steel product industries, is not regarded to be a toxic and hazardous waste major, it is nonetheless catalogued as a producer of such waste, primarily in connection with certain finishing process byproducts such as varnish. Consequently, further to environmental legislation (5), it is incumbent upon the industry to implement suitable management measures for this waste.

The waste obtained from sanding/polishing varnished products (VP) was used and analyzed in this first-stage study. As very fine powders, they can be readily mixed with wet clay, which must, however, be pre-treated before mixing.

Various types of varnish, with different chemical compositions, may be used for the final finishes on wood products (6) such as doors, furniture, structural members and so on. Polyurethane is the most common compound both for undercoats (nearly $90 \%$ of the products used contain it) and finishes (50\% of products have a polyurethane base).

The primary purpose of adding VP to the clay mixes was to be able to permanently eliminate this potentially pollutant waste whose management and re-use are particularly complex. When encapsulated in the clay paste and subsequently fired, the fumes are filtered by the clay itself, which eliminates the volatile pollutant compounds. Only inert gas is released into the atmosphere, and at that in proportions under the ceilings stipulated in the existing legislation. Solid PV waste is fixed in the molecular structure of the compound in such a way that it cannot be released into the environment either by leaching or decomposition.

The addition of agricultural (olive dregs or pits), wood industry (saw, paper mill cellulose) or synthetic (polystyrene and other petroleum derivatives) organic materials 
industria del papel) o sintéticos (poliestireno y otros derivados del petróleo), es una práctica común en la industria cerámica (7), ya que permite aportar energía en la cocción de los productos cerámicos y, en algunos casos, mejorar algunas propiedades físicas y mecánicas de estos productos, por lo que se consideró también que la adición de PLB de la industria de la madera podría contribuir a la mejora del producto cerámico y a valorizar este residuo peligroso.

La información obtenida en relación a la cantidad de PLB que se recoge anualmente en la industria de la madera de Castilla-La Mancha (Tabla 1) se refiere a los años 2000, 2001 y 2002, y corresponde sólo a empresas que contratan la gestión de residuos. De estos datos podemos determinar que cada empresa produce una media de más de $2.600 \mathrm{~kg}$ de PLB al año, que además ha habido un incremento del $90 \%$ de empresas que gestionan este tipo de RTP en los tres años analizados. to pastes is common practice in the clay industry (7), for it is a way of enhancing the energy content of clay products and in some cases improving certain physical and mechanical properties of the finished materals. For this reason, the addition of wood industry VP was considered to be a possible way of improving clay products while at the same time re-using this hazardous waste.

The information given in Table 1 below on the amount of VP collected yearly in Castilla-La Mancha, referred to years 2000, 2001 and 2002, was furnished by waste management companies. According to these Figures, each company may be estimated to collect an average of $2,600 \mathrm{~kg}$ of VP yearly, while the number of companies managing this type of HTW grew by $90 \%$ in the three years analyzed.

Tabla 1 / Table 1

Gestión de PLB en industrias de la madera en Castilla-La Mancha Reuse of wood industry waste in Castilla-La Mancha

\begin{tabular}{|lccc|}
\hline $\begin{array}{l}\text { Año } \\
\text { Year }\end{array}$ & $\begin{array}{c}\text { No de empresas } \\
\text { No. of companies }\end{array}$ & $\begin{array}{c}\text { Cantidad recogida en } \mathbf{k g} \\
\text { Amount collected in } \mathbf{~ g g}\end{array}$ & $\begin{array}{l}\text { kg/empresa } \\
\mathbf{k g} / \mathbf{c o m p a n y}\end{array}$ \\
\hline 2000 & 21 & 59340 & 2825.71 \\
\hline 2001 & 33 & 88478 & 2681.15 \\
\hline 2002 & 43 & 104000 & 2418.60 \\
\hline Media / Average & & & 2641.82 \\
\hline
\end{tabular}

Datos: AIMCM-CTM / Source: AIMCM-CTM.

(Años 2000, 2001 y 2002) / (Years 2000, 2001 y 2002)

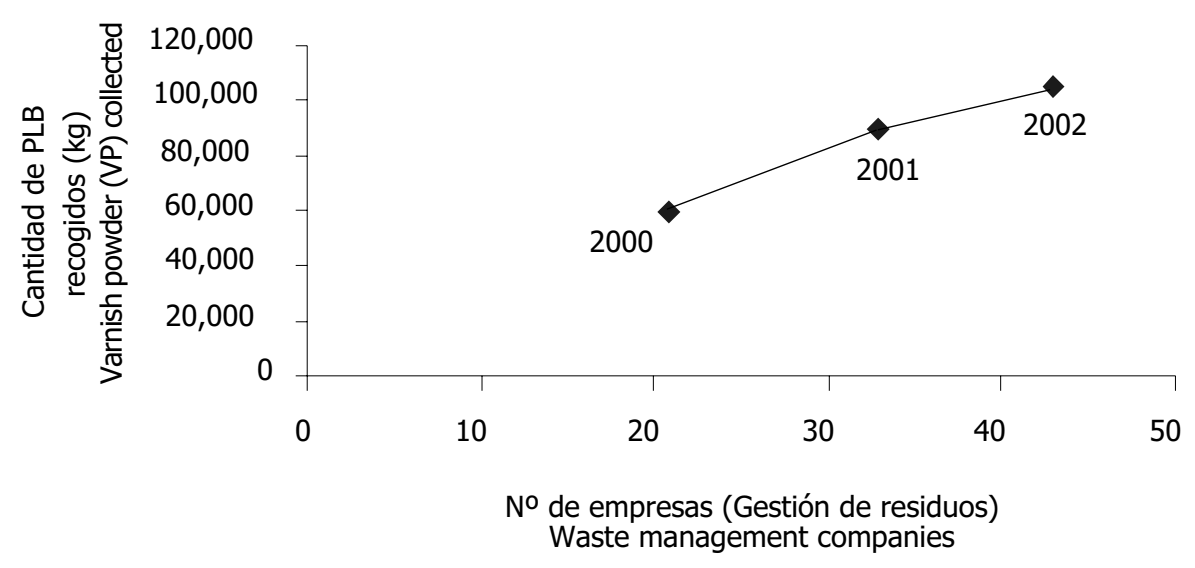

Figura 1. Polvos de lijado de barniz recogidos a través de gestores de residuos en empresas de la madera de CLM (elaboración propia).

Figure 1. Varnish powder (VP) collected by waste management companies from wood industry plants in Castilla-La Mancha (formulated by the authors). 
Tomando en cuenta que la cantidad de PLB recogida en empresas de CLM en el año 2002 fue de 104.000 kg, significa que la región estaría en capacidad de suministrar $5.200 .000 \mathrm{~kg}$ de este material para elaborar productos cerámicos con la mezcla de xiloarcilla (al 2\% de PLB) para esta industria.

Se llevaron a cabo diferentes análisis y ensayos a los polvos de lijado de los barnices (PLB), entre los que destacamos para este trabajo los siguientes:

\subsubsection{Análisis químico de mayoritarios del PLB}

Este análisis químico se llevó a cabo en el Departamento de Química-Física, Laboratorio de Mineralogía aplicada de la Universidad de Castilla-La Mancha (8). Los resultados obtenidos, se indican en la Tabla 2 .

El 95\% son volátiles (pérdida por calcinación; PPC) que corresponde a materia orgánica.

\subsubsection{Análisis de toxicidad de los humos del PLB}

Este análisis se realizó según la norma NF 16101 (9). Los resultados obtenidos se indican en la siguiente Tabla 3.

\subsubsection{Potencial calorífico superior del PLB}

El ensayo de poder calorífico superior (PCs) de los PLB, se realizó de acuerdo a la norma UNE - ISO 1716 (10).

Se comparan los datos del PCs de este producto con otros utilizados a menudo como adiciones a la mezcla de las arcillas para ladrillos (Tabla 4).
Based on the amount of VP collected from companies in Castilla-La Mancha in $2002-104,000 \mathrm{~kg}$ - the region may be estimated to be able to produce $5,200,000 \mathrm{~kg}$ of xiloarcilla mix (containing $2 \% \mathrm{VP}$ ) for the manufacture of clay products.

The analyses and tests conducted on varnish powder (VP) for this study are discussed below.

\subsubsection{Chemical analysis of majority vp components}

Chemical analyses conducted in the University of CastiIla-La Mancha Physical Chemistry Department's Mineralogy Laboratory (8). The results obtained are given in Table 2.

All of the volatile material $-95 \%$ of the total- lost on calcination (LOC) is organic.

\subsubsection{Analysis of VP fume toxicity}

This analysis was conducted to standard NF 16101 (9). The results obtained are given in Table 3 below.

\subsubsection{VP high heat value}

The VP was tested for high heat value as described in Spanish and international standard UNE - ISO 1716 (10).

The high heat values for this product are compared to the values for products often used as additions in clay brick manufacture (Table 4).

Tabla 2 / Table 2

Cantidad de compuestos químicos del PLB VP chemical composition

\begin{tabular}{|lccccccccccc|}
\hline$\%$ & $\mathrm{SiO}_{2}$ & $\mathrm{Al}_{2} \mathrm{O}_{3}$ & $\mathrm{Fe}_{2} \mathrm{O}_{3}$ & $\mathrm{MgO}$ & $\mathrm{CaO}$ & $\mathrm{K}_{2} \mathrm{O}$ & $\mathrm{TiO}_{2}$ & $\mathrm{P}_{2} \mathrm{O}_{5}$ & $\mathrm{ZnO}$ & $\mathrm{BaO}$ & $\mathrm{PPC}$ \\
\hline $\mathrm{PLB}$ & 3.011 & 0.093 & 0.057 & 1.258 & 0.166 & 0.022 & 0.052 & 0.089 & 0.055 & 0.006 & 95.168 \\
\hline
\end{tabular}

Tabla 3 / Table 3

Valores del análisis de toxicidad de humos

Fume toxicity analysis values

\begin{tabular}{|ll|}
\hline $\begin{array}{l}\text { mg gas/g material } \\
\mathbf{m g} \text { gas } / \mathbf{g} \text { material }\end{array}$ & $\begin{array}{l}\text { Contenido químico de los humos de los polvos de lijado de barnices (PLB) } \\
\text { Chemical content of fume varnish powder }\end{array}$ \\
\hline $\mathrm{HCl}$ & 1.42 \\
\hline $\mathrm{HBr}$ & No detectado / Not detected \\
\hline $\mathrm{HF}$ & 0.17 \\
\hline $\mathrm{CO}$ & 287.16 \\
\hline $\mathrm{CO}_{2}$ & 502.91 \\
\hline $\mathrm{SO}_{2}$ & 0.03 \\
\hline $\mathrm{NOx}$ & 0.025 \\
\hline $\mathrm{HCN}$ & 0.05 \\
\hline
\end{tabular}




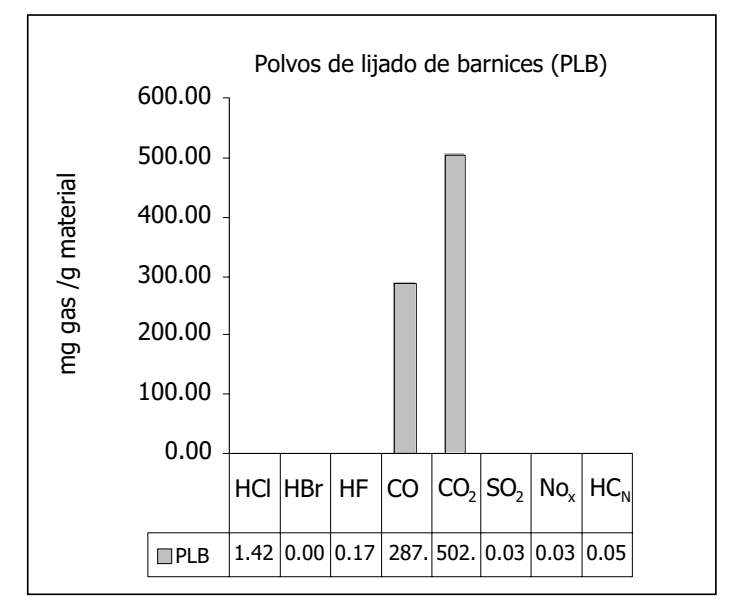

Figura 2. Compuestos predominantes de los humos de los PLB.

Figure 2. Predominant compounds in VP fumes.

Tabla 4 / Table 4

Valores de PCs en diferentes materiales

High heat values for different materials

\begin{tabular}{|lcc|}
\hline & $\begin{array}{c}\text { PCs - MJ/kg } \\
\text { Materiales / Materials }\end{array}$ & $\begin{array}{c}\text { kcal/kg } \\
\text { kcal//kg }\end{array}$ \\
\hline Polvo de lijado del barniz / Varnish powder - VP & 23.3639 & 5589.45 \\
\hline Orujo + hueso de aceituna (A) / Olive dregs + pits (A) & 19.0563 & 4558.92 \\
\hline Orujo + hueso de aceituna (B) / Olive dregs + pits (B) & 22.3247 & 5340.84 \\
\hline Madera de encina seca / Dry holm oak wood & 20.2632 & 4847.66 \\
\hline Madera de encina húmeda / Wet holm oak wood & 19.7127 & 4715.96 \\
\hline Madera de roble / Oak wood & 20.6679 & 4944.47 \\
\hline Madera de sapelly / Sapelly wood & 20.8353 & 4984.52 \\
\hline Serrín / Saw dust & 20.9719 & 5017.20 \\
\hline Tablero de p. rechapado sapelly y barnizado / Door panel with varnished sapelly veneering & 22.7064 & 5432.15 \\
\hline Celulosa / Cellulose & 19.2280 & 4600.00 \\
\hline Poliestireno / Polystyrene & 37.6200 & 9000.00 \\
\hline
\end{tabular}

El PCs de los PLB es superior que los PCs de muchos productos utilizados frecuentemente junto con las arcillas, para aportar energía calorífica durante la cocción, como se aprecia en la Tabla 4, con excepción del poliestireno que tiene un poder calorífico mayor, sin embargo, este producto es utilizado con la finalidad de producir arcillas aligeradas y con propiedades térmicas y acústicas especiales.

También se determinó en otro ensayo que la temperatura media de combustión de los PLB está alrededor de los $350{ }^{\circ} \mathrm{C}$, lo que significa que este producto se volatiliza mucho antes de la cocción de las arcillas.

\subsection{Las arcillas}

Se determinó el tipo de arcilla a utilizar como producto base para la mezcla con los residuos de la madera y específicamente con los PLB.
As Table 4 shows, VP high heat value is greater than the values for most of the substances frequently added to clay to enhance heat energy during firing; the exception is polystyrene, which has a higher value, although this compound is used for a different purpose, namely to produce lightweight clay with special thermal and acoustic properties.

The average combustion temperature of VP was determined to be around $350^{\circ} \mathrm{C}$; i.e., this powder is volatized long before the clay is fully fired.

\subsection{Clays}

One of the intermediate objectives of the study was to determine the most suitable type of clay to use as a matrix for wood waste, specifically VP. 
Tabla 5 / Table 5

Composición mineralógica de las arcillas (\% peso) (AITEMIN, comunicación privada) Mineralogical composition of clays (\% wt) (AITEMIN, private communication)

\begin{tabular}{|c|c|c|c|c|c|c|c|c|}
\hline $\begin{array}{l}\text { Arcilla } \\
\text { Clay }\end{array}$ & $\begin{array}{l}\text { Cuarzo } \\
\text { Quartz } \\
\end{array}$ & $\begin{array}{c}\text { Feldespato K } \\
\text { K Feldespar }\end{array}$ & $\begin{array}{l}\text { Plagioclasas } \\
\text { Plagioclases }\end{array}$ & $\begin{array}{l}\text { Calcita } \\
\text { Calcite }\end{array}$ & $\begin{array}{l}\text { Dolomita } \\
\text { Dolomite }\end{array}$ & $\begin{array}{c}\text { Filo-silicatos } \\
\text { Phyllo-silicates }\end{array}$ & $\begin{array}{l}\text { Ilita } \\
\text { Illite }\end{array}$ & $\begin{array}{l}\text { Caolinita } \\
\text { Kaolinite }\end{array}$ \\
\hline EPH3 / La Sagra & 6 & 12 & 8 & $<5$ & $<5$ & 67 & Dominante & Poco contenido \\
\hline
\end{tabular}

Se escogieron las arcilla de la región de La Sagra, por su calidad y sus características, al ser ésta una materia prima utilizada por las plantas productoras de materiales de construcción a base de arcilla. Los datos referidos a la composición mineralógica así como la gráfica del ensayo de difracción de RX de la arcilla utilizada, denominada como EPH 03, han sido suministrados por AITEMIN (4). Es una arcilla que se ha utilizado como matriz para el compuesto que denominamos xiloarcilla, que contiene la mezcla de la arcilla con los PLB.

Se incluye a continuación la Tabla 5 de la composición mineralógica del ensayo de difracción de RX del producto EPH 03, arcillas de la zona de La Sagra (Toledo).

\section{EL COMPUESTO XILOARCILLA Y EL PLAN DE ENSAYOS}

Caracterizados separadamente los materiales que conforman el compuesto de xiloarcilla, a través de la mezcla de la arcilla (EPH 03) como matriz con las adiciones de los PLB, se procedió a determinar las mezclas más convenientes para lograr las mejores prestaciones de la xiloarcilla, aportando, por una parte, energía para la cocción, por otra, la mejora de propiedades físicas (disminución del peso) y mecánicas (resistencia a flexión) de los productos cerámicos $\mathrm{y}$, en especial, poder fijar el producto PLB, residuo de las industrias de la madera, en un material que pudiera actuar de filtro.

Para la preparación de las mezclas de materias primas en la fabricación de probetas, en primer lugar se tanteó la mezcla máxima de cada residuo que admite la arcilla en cocción a $950{ }^{\circ} \mathrm{C}$ de temperatura máxima, siguiendo la curva diseñada temperatura-tiempo estándar, sin inflamarse ni fracturarse. Se anotó la cantidad de agua empleada en el amasado para conseguir una plasticidad equivalente, con las distintas y crecientes cantidades de residuos.

Tras la mezcla y cocción, se determinaron las propiedades físicas y mecánicas de las mezclas de arcilla y PLB, así como los valores de la lixiviación del compuesto xiloarcilla.

Además de la fabricación de probetas artesanales en el CTM, se elaboraron probetas extrusionadas. Se fabricaron
The one found to have optimum quality and features in this respect was the La Sagra region clay, denominated $E P H 03$, used as a prime material by plants engaging in the manufacture of clay brick and similar construction products. The data on the mineralogical composition as well as the XRD pattern for the clay used as the matrix for the material here called xiloarcilla were furnished by AITEMIN (4).

The mineralogical composition of EPH 03, determined with $X$-ray diffraction techniques, is given in Table 5 below.

\section{THE XILOARCILLA COMPOUND AND THE TEST PLAN}

After the materials comprising xiloarcilla were characterized separately, tests were conducted to identify the clay (EPH-03)-VP mixes that would yield a compound with the best performance in terms of: energy supply for firing, improvement of the physical (lower weight) and mechanical (higher bending strength) properties of the clay product, and especially the fixation of the VP wood industry waste in a material able to serve as a filter.

To prepare the mixes for the specimens, a standard time-temperature curve was used to find the highest proportion of waste that the clay could accommodate when fired at temperatures of up to $950^{\circ} \mathrm{C}$ without burning or breaking. The amount of water used in the mix was recorded to ensure equivalent plasticity with the increasing proportions of waste.

The physical and mechanical properties of the clay-VP mixes, as well as the leaching values for the xiloarcilla product, were determined after firing.

In addition to hand-made specimens, extruded specimens were manufactured at the CTM. A total of 28 
en cantidad suficiente para su evaluación posterior, 28 probetas para cada fracción de cada tipo de residuos. Se anotaron las cantidades de agua de amasado para conseguir una plasticidad semejante y comparable entre las distintas probetas con diferentes y crecientes cantidades de residuos. La cocción se hizo a diferentes temperaturas 900, 925 y $950^{\circ} \mathrm{C}$. Se elaboraron probetas de la mezcla que denominamos xiloarcilla con las dimensiones de $125 \times 25$ $\mathrm{x} 15 \mathrm{~mm}$, cocidas a las diferentes temperaturas indicadas, optando finalmente por la temperatura de $925^{\circ} \mathrm{C}$ para la mayoría de las probetas, de acuerdo a los resultados obtenidos en los primeros ensayos realizados en el CTM.

En esta etapa del proyecto se completaron diferentes ensayos tecnológicos (11) para poder determinar la conveniencia o no de la adición del subproducto PLB, así como la proporción (\%) de adición de este subproducto más conveniente para la mezcla de xiloarcilla.

Los análisis y ensayos realizados se agrupan en tres y, de forma resumida, fueron los siguientes:

- Sobre las características físicas de la xiloarcilla. Densidades, porosidad, humedad de moldeo, agua de revenido, coeficiente de absorción, succión, contracción a diferentes temperaturas de cocción (900, 925 y $950^{\circ} \mathrm{C}$ ), eflorescencias, deformaciones.

- Ensayos relacionados con las propiedades mecánicas. Resistencia a flexión, resistencia a compresión y módulo de elasticidad.

- Los ensayos de caracterización química de los PLB, así como los relacionados con la toxicidad de los humos y análisis de los lixiviados de la xiloarcilla.

\section{RESULTADOS Y DISCUSIÓN}

Se presentan en este apartado aquellos valores de los ensayos que tienen un mayor interés para el análisis del compuesto xiloarcilla. specimens were made per fraction of waste type. The amounts of water used in the mix were recorded to ensure similar and comparable plasticity in the different specimens, which contained increasing proportions of waste. Xiloarcilla specimens measuring $125 x$ $125 \times 15 \mathrm{~mm}$ were fired at temperatures of 900, 925 and $950{ }^{\circ} \mathrm{C}$. Pursuant to the results of the first tests conducted at the CTM, $925^{\circ} \mathrm{C}$ was established as the optimum temperature for most of the specimens.

A number of different technological tests (11) were conducted in this stage to determine the suitability or otherwise of the VP by-product as an addition, as well as the most appropriate proportion (\%) for the xiloarcilla mix.

Three types of analyses and tests were run, as follows:

- Tests to determine product physical properties. Density, porosity, moulding humidity, pre-firing post-drying moisture, absorption coefficient, suction, shrinkage at different firing temperatures $\left(900,925,950^{\circ} \mathrm{C}\right)$, efflorescence and deformation.

- Tests to determine product mechanical properties. Flexural and compressive strength and modulus of elasticity.

- Chemical characterization of the VPs, with tests relating to fume toxicity and xiloarcilla leachate analysis.

\section{RESULTS AND DISCUSSION}

The test values of greatest relevance to xiloarcilla composition are discussed below.

Tabla 6 / Table 6

Valores de humedad, contracción de secado y contenido de agua de las mezclas Moisture, drying shrinkage and water content in mixes

\begin{tabular}{|c|c|c|c|c|}
\hline $\begin{array}{l}\text { Cantidad de PLB* } \\
\text { Amount of VP }\end{array}$ & $\begin{array}{l}\text { Probeta PLB } \\
\text { VP SPECIMEN }\end{array}$ & $\begin{array}{c}\text { Humedad moldeo } \% \mathrm{H}_{2} \mathrm{O} \\
\text { Moulding moisture }\left(\% \mathrm{H}_{2} \mathrm{O}\right)\end{array}$ & $\begin{array}{c}\text { Contracción secado \% } \\
\text { Drying shrinkage \% }\end{array}$ & $\begin{array}{l}\left.\text { Agua revenido \% (Absorción de } \mathrm{H}_{2} \mathrm{O}\right) \\
\text { Moisture content } 1 \text { \% ( } \mathrm{H}_{2} \mathrm{O} \text { absorption) }\end{array}$ \\
\hline $0 \%$ & Xi 0 & 25.58 & 7.37 & 6.97 \\
\hline $1 \%$ & Xi 1 & 23.46 & 6.35 & 6.54 \\
\hline $2 \%$ & Xi 2 & 23.91 & 6.01 & 6.47 \\
\hline $3 \%$ & Xi 3 & 24.11 & 5.97 & 5.83 \\
\hline $4 \%$ & Xi 4 & 25.03 & 6.46 & 5.14 \\
\hline $5 \%$ & Xi 5 & 26.04 & 6.57 & 5.75 \\
\hline
\end{tabular}

1 Pre-firing, post-drying.

* En peso \% / by wt. 


\subsection{Sobre los ensayos físicos y mecánicos}

El agua requerida para el amasado de la mezcla de xiloarcilla disminuye con porcentajes de adición de PLB entre el $1 \%$ y el $3 \%$, y aumenta por encima del $4 \%$ (Figura 3).

La contracción lineal de las probetas de xiloarcilla es menor cuando tienen adiciones de PLB, siendo mayor cuando la mezcla no tiene adiciones (Figura 4).

El límite máximo de la longitud de loseta de xiloarcilla sin fisurar es mayor con adiciones de $2 \%$ y $3 \%$, llegando a ser cinco veces mayor este límite que la arcilla sin adiciones.

Las densidades reales y aparentes de la xiloarcilla son menores aunque muy similares a las de la arcilla sin adiciones (Figura 5).

El coeficiente de absorción y la succión de la xiloarcilla con adiciones del $1 \%$ y $2 \%$ es similar al de la arcilla sin adiciones. Al aumentar sobre el 3\% la adición de PLB a la mezcla, aumenta el coeficiente de absorción y la succión (Figura 6).

La resistencia a flexión de la xiloarcilla es mayor $(18,12 \%$ y $19,5 \%$ ) que la de las arcillas sin adiciones, cuando el porcentaje de los PLB está entre el $1 \%$ y $2 \%$. La resistencia a flexión disminuye de manera importante cuando la adición de PLB supera el 3\% (Figura 7).

La resistencia a flexión de la xiloarcilla es algo mayor cuando la temperatura de cocción es de $925^{\circ} \mathrm{C}$ (se cocieron las probetas con 3 diferentes temperaturas de cocción, a 900,925 y $\left.950^{\circ} \mathrm{C}\right)$.

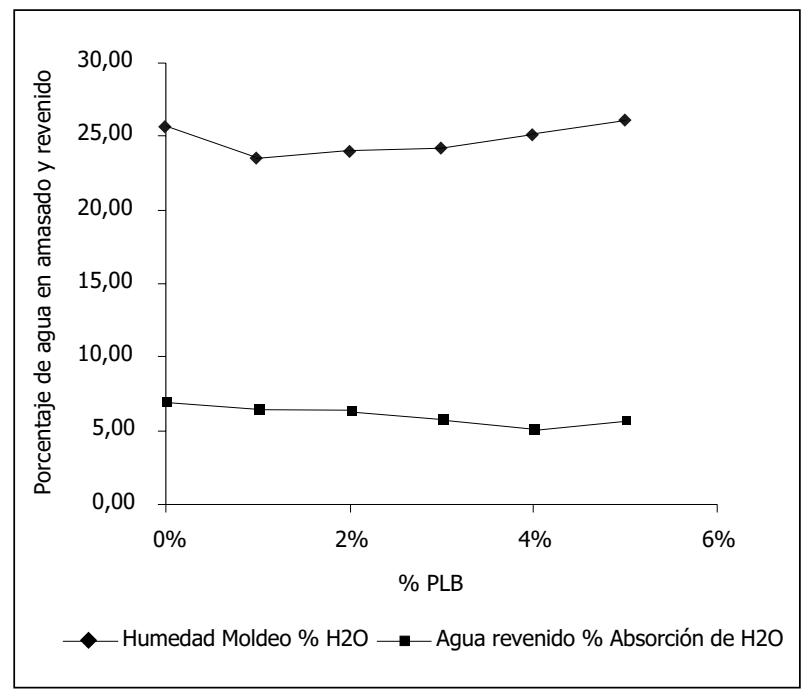

Figura 3. Cantidad (en \%) de agua durante el amasado, con cantidad de PLB.

Figure 3. Amount (in \%) of water during mixing vs amount of VP.

\subsection{Physical and mechanical tests}

The mixing water required to prepare xiloarcilla declines when the percentage at VP percentages of from $1 \%$ to $3 \%$, and increases from $4 \%$ on (Figure 3 ).

Linear shrinkage is smaller in the xiloarcilla specimens (with VP additions) than the specimens with no additions (Figure 4).

Xiloarcilla tiles containing 2\% and 3\% additions attain maximum lengths without cracking that are up to five times greater than attained by clay tiles with no additions.

Xiloarcilla real and bulk density is lower than, although similar to, the density values in clay with no additions (Figure 5).

In Xiloarcilla made with $1 \%$ and $2 \%$ additions the absorption coefficient and suction are similar to the values for clay with no additions. Both absorption coefficients and suction rise when the proportion of the VP added is over 3\% (Figure 6).

When the proportion of VP is between $1 \%$ and $2 \%$, Xiloarcilla bending strength is higher than in clay with no additions (19.5\% compared to $18.2 \%)$. Flexural strength declines steeply at VP values of over $3 \%$, however (Figure 7).

Xiloarcilla flexural strength is somewhat higher when the firing temperature is $925{ }^{\circ} \mathrm{C}$ (specimens were fired at three different temperatures: 900, 925 and $950^{\circ} \mathrm{C}$ ).

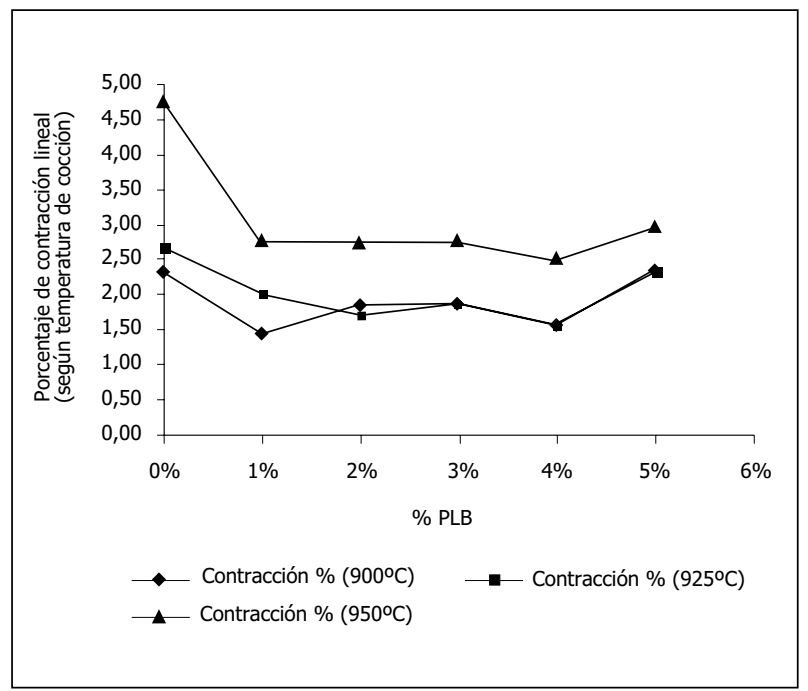

Figura 4. Contracción de las probetas según la temperatura de cocción.

Figure 4. Specimen shrinkage by firing temperature. 


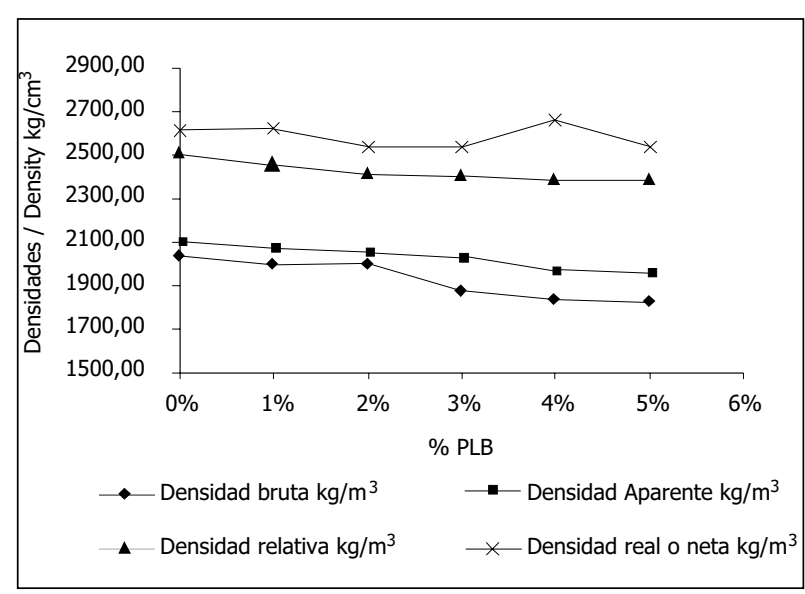

Figura 5. Variación de la densidad de la xiloarcilla con la adición de PLB.

Figure 5. Xiloarcilla density vs percentage of VP.

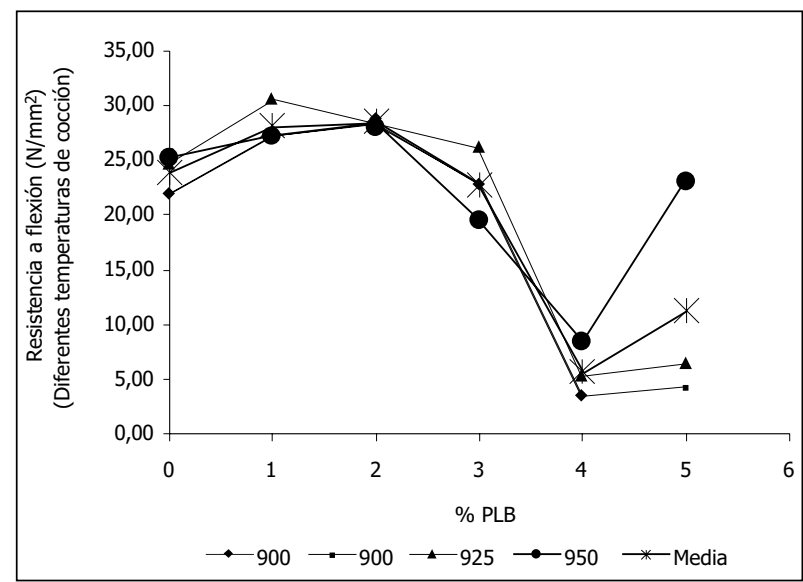

Figura 7. Variación de la resistencia a flexión, con la cantidad de PLB.

Figure 7. Flexural strength vs percentage of VP.

El módulo de elasticidad de la xiloarcilla disminuye con la adición de los PLB y es menor que las arcillas sin adiciones.

La resistencia a compresión de la xiloarcilla es superior a la de la arcilla sin adiciones cuando los porcentajes de PLB están entre el $1 \%$ y el $3 \%$ (hasta el $22 \%$ de incremento de la resistencia), con temperaturas de cocción de 925 y $950{ }^{\circ} \mathrm{C}$, disminuyendo la resistencia con adiciones de PLB por encima del 3\% (Figura 8).

\subsection{Sobre los ensayos químicos del compuesto xiloarcilla}

Toxicidad de los humos de la xiloarcilla

El ensayo se realizó siguiendo las directrices de la normativa de determinación de la toxicidad de humos de

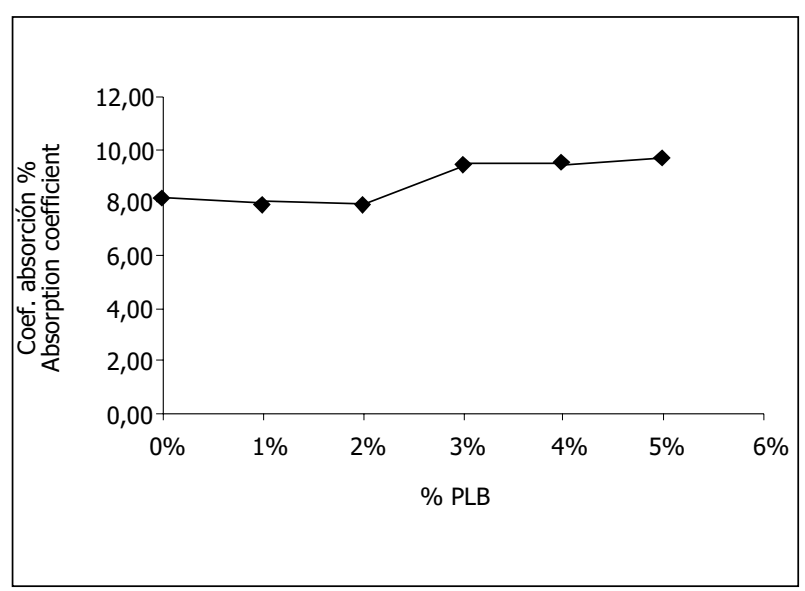

Figura 6. Variación del coeficiente de absorción de la xiloarcilla, con la adición de PLB.

Figure 6. Xiloarcilla absorption coefficient vs percentage of VP.

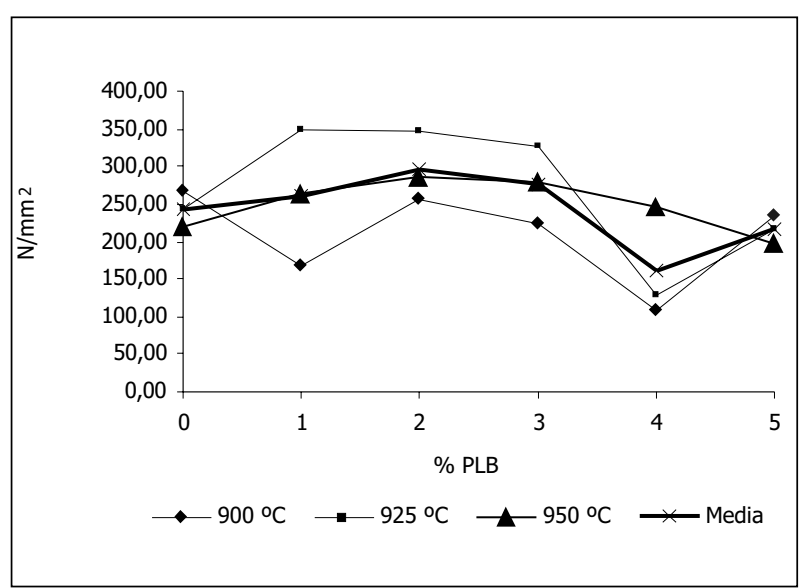

Figura 8. Comparación de resistencia a compresión de la xiloarcilla con diferentes contenidos (\%) de PLB y a diferentes temperaturas de cocción.

Figure 8. Xiloarcilla compressive strength vs VP content (\%) at different firing temperatures.

Xiloarcilla modulus of elasticity declines with VP additions.

Xiloarcilla compressive strength is up to $22 \%$ greater than in clay with no additions when the proportion of VP added is from $1 \%$ to $3 \%$ and the firing temperature is 925 or $950^{\circ} \mathrm{C}$; strength declines, however, with VP additions of over $3 \%$ (Figure 8 ).

\subsection{Chemical tests}

\section{Xiloarcilla fume toxicity}

This test was conducted with the tubular oven trial described in standard NF X 70100 (9) in accordance with 
Tabla 7 / Table 7

Límites de emisión fijados por legislación vigente en comparación con la medidas de contaminantes emitidos a la atmósfera analizados

Emission ceilings under existing legislation and pollutant emissions for the materials analyzed

\begin{tabular}{|c|c|c|c|c|}
\hline $\begin{array}{l}\text { Contaminante } \\
\text { Pollutant }\end{array}$ & $\begin{array}{l}\text { Límite de emisión (referencia) } \\
\text { Emission ceiling (Benchmark) }\end{array}$ & $\begin{array}{l}\text { Arcilla } \\
\text { Clay }\end{array}$ & $\begin{array}{c}\text { Arcilla }+2 \% \text { PLB } \\
\text { Clay }+2 \% \text { VP }\end{array}$ & $\begin{array}{c}\text { Arcilla }+5 \% \text { PLB } \\
\text { Clay }+5 \% \text { VP }\end{array}$ \\
\hline $\mathrm{CO}$ & $500 \mathrm{ppm}(\mathrm{a})$ & $1.5 \times 10^{-2} \mathrm{ppm}^{*}$ & $5.7 \times 10-1 \mathrm{ppm}^{*}$ & $1.28 \mathrm{ppm}^{*}$ \\
\hline $\mathrm{CO}_{2}$ & depende licencia (b) & $0 \mathrm{mg} / \mathrm{Nm}^{3}{ }^{*}$ & $3602 \mathrm{mg} / \mathrm{Nm}^{3}{ }^{*}$ & $10330 \mathrm{mg} / \mathrm{Nm}^{3}{ }^{*}$ \\
\hline $\mathrm{NO}_{\mathrm{x}}$ & $1300-450 \mathrm{mg} / \mathrm{Nm}^{3}{ }^{* *}(\mathrm{c})$ & 10.5 & 20.3 & 14.6 \\
\hline $\mathrm{SO}_{\mathrm{x}}$ & $2000-400 \mathrm{mg} / \mathrm{Nm}^{3}{ }^{* *}(\mathrm{~d})$ & 7.8 & 42.4 & 18.6 \\
\hline $\begin{array}{l}\text { Cloro y sus compuestos inorgánicos } \\
\text { Chlorine and } \mathrm{Cl} \text { inorganic compounds }\end{array}$ & $460 \mathrm{mg} / \mathrm{Nm}^{3}(\mathrm{a})$ & 135.6 & 103.4 & 84.7 \\
\hline $\begin{array}{l}\text { Flúor y sus compuestos inorgánicos } \\
\text { Fluorine and F inorganic compounds }\end{array}$ & $80 \mathrm{mg} / \mathrm{Nm}^{3}$ (a) & 62.7 & 47.5 & 42.3 \\
\hline $\begin{array}{l}\text { PM10/ partículas } \\
\text { PM10/particles }\end{array}$ & $50-100 \mathrm{mg} / \mathrm{Nm}^{3}$ (c) & - & - & - \\
\hline
\end{tabular}

* Tener en cuenta que para comparar con el límite de emisión habría que sumarle la emisión de CO en el horno debida a la combustión / For a valid comparison, CO emissions owing to combustion must be added to the Figure shown.

** Dependiendo si es aplicable o no RD 646/1991y RD 1800/1995 y del tipo de instalación / Depending on whether RD 646/1991 or RD 1800/1995 is applicable, and the type of facility.

Referencias/References:
(a) RD 833/1975.
(b) Directiva / Directive 2003/87/CE.
(c) RD 646/1991.
(d) RD 1800/1995.

combustión mediante el ensayo de horno tubular NF X 70100 (9).

En las Tablas 7 y 8 se recogen los valores límite de emisión fijados por legislación vigente (12).

A) Suponiendo que los datos facilitados son de una instalación con horno Hoffman con una emisión de aire de $5.900 \mathrm{~m}^{3} / \mathrm{t}$.

Se realizó el mismo análisis con otros tipos de instalación.

B) Suponiendo que los datos facilitados son de una instalación con horno $\mathrm{H}$. Tunel con una emisión de aire de $1.500 \mathrm{~m}^{3} / \mathrm{t}$.

Estudio de los lixiviados de la xiloarcilla con 3\% y con 5\% $\underline{\text { de PLB en el compuesto }}$

Los contenidos en metales pesados de las muestras con diferentes contenidos de PLB son análogos a los de las muestras patrones sin PLB, y muy por debajo de los valores que pudieran considerarse como contaminantes, por lo que este material también puede ser utilizado en la fabricación de cerámica cara vista $(8,13)$. the guidelines set out in the legislation on determining combustion fume toxicity.

Tables 7 and 8 give the emission ceilings laid down in the existing legislation (12).

A) Assuming that the Figures shown are for a Hoffman oven with an air emission rate of $5900 \mathrm{~m}^{3} / \mathrm{t}$.

The same analysis was conducted with other types of facilities.

B) Assuming that the Figures shown are for a tunnel oven with an air emission rate of $1,500 \mathrm{~m}^{3} / \mathrm{t}$.

\section{3\% and 5\%-VP xiloarcilla leachates}

The heavy metal content in samples with proportions of $V P$ is analogous to the findings for control samples with no VP and far below what might be regarded to be pollutant values; this material may also be used, therefore, in fair-faced or exposed materials $(8,13)$. 
Tabla 8 / Table 8

Límites de emisión fijados por legislación vigente (12)

Emission ceilings under existing legislation

\begin{tabular}{|c|c|c|c|c|}
\hline $\begin{array}{l}\text { Contaminante } \\
\text { Pollutant }\end{array}$ & $\begin{array}{l}\text { Límite de emisión (referencia) } \\
\text { Emission ceiling (Benchmark) }\end{array}$ & $\begin{array}{c}\text { Arcilla } \\
\text { Clay }\end{array}$ & $\begin{array}{c}\text { Arcilla }+2 \% \text { PLB } \\
\text { Clay }+2 \% \text { VP }\end{array}$ & $\begin{array}{c}\text { Arcilla }+5 \% \text { PLB } \\
\text { Clay }+5 \% \text { VP }\end{array}$ \\
\hline \multicolumn{5}{|l|}{$+5 \%$ PLB } \\
\hline $\mathrm{CO}$ & 500 ppm (a) & $6.0 \times 10^{-2} \mathrm{ppm}^{*}$ & $2.2 \mathrm{ppm} *$ & $5.1 \mathrm{ppm} *$ \\
\hline $\mathrm{CO}_{2}$ & depende licencia (b) & $0 \mathrm{mg} / \mathrm{Nm}^{3}{ }^{*}$ & $14167 \mathrm{mg} / \mathrm{Nm}^{3}$ * & $40633 \mathrm{mg} / \mathrm{Nm}^{3}{ }^{*}$ \\
\hline $\mathrm{NO}_{\mathrm{x}}$ & $1300-450 \mathrm{mg} / \mathrm{Nm}^{3}{ }^{* *}$ (c) & 41.3 & 80.0 & 57.3 \\
\hline $\mathrm{SO}_{\mathrm{x}}$ & $2000-400 \mathrm{mg} / \mathrm{Nm}^{3 * *}(\mathrm{~d})$ & 30.7 & 166.7 & 73.3 \\
\hline $\begin{array}{l}\text { Cloro y sus compuestos inorgánicos } \\
\text { Chlorine and } \mathrm{Cl} \text { inorganic compounds }\end{array}$ & $460 \mathrm{mg} / \mathrm{Nm}^{3}$ (a) & 533.3 & 406.7 & 333.3 \\
\hline $\begin{array}{l}\text { Flúor y sus compuestos inorgánicos } \\
\text { Fluorine and F inorganic compounds }\end{array}$ & $80 \mathrm{mg} / \mathrm{Nm}^{3}$ (a) & 246.7 & 186.7 & 166.7 \\
\hline $\begin{array}{l}\text { PM10/ partículas } \\
\text { PM10/particles }\end{array}$ & $50-100 \mathrm{mg} / \mathrm{Nm}^{3}$ (c) & - & - & - \\
\hline
\end{tabular}

* Tener en cuenta que para comparar con el límite de emisión habría que sumarle la emisión de CO en el horno debida a la combustión / For a valid comparison, CO emissions owing to combustion must be added to the Figure shown.

** Dependiendo si es aplicable o no RD 646/1991 y RD 1800/1995 y del tipo de instalación / Depending on whether RD 646/1991 or RD 1800/1995 is applicable, and the type of facility.

Referencias/References:
(a) RD 833/1975.
(b) Directiva / Directive 2003/87/CE.
(c) RD 646/1991.
(d) RD 1800/1995.
(En negrita los valores que están por encima de la legalidad) / (Bold denotes values exceeding the legal limits)

Tabla 9 / Table 9

Análisis químico de metales pesados de interés medioambiental en probetas con diferentes cantidad (\%) de adición de PLB Chemical analysis of heavy metals of environmental relevance in specimens with different VP content (\%)

\begin{tabular}{|lccc|}
\hline & Xi $0 \%$ PLB & Xi 3\% PLB & Xi 5\% PLB \\
\hline $\mathrm{Ni}(\mathrm{mg} / \mathrm{l})$ & 0.02 & 0.02 & 0.01 \\
\hline $\mathrm{Pb}(\mathrm{mg} / \mathrm{l})$ & 0.02 & 0.04 & 0.04 \\
\hline $\mathrm{Cd}(\mathrm{mg} / \mathrm{l})$ & N.D. & 0.01 & 0.01 \\
\hline $\mathrm{Cr}(\mathrm{mg} / \mathrm{l})$ & 0.01 & N.D. & N.D. \\
\hline $\mathrm{As}(\mathrm{mg} / \mathrm{l})$ & 0.02 & 0.06 & 0.07 \\
\hline
\end{tabular}

\section{CONCLUSIONES}

Los resultados en este estudio, referidos a las características físico-mecánicas de la xiloarcilla, durante la fabricación y después de la cocción de las probetas, muestran valores que nos permiten afirmar que es factible la valorización de un residuo de la industria de la madera como son los polvos de lijado de productos barnizados, mezclados con polvos de barnizado de este residuo (PLB). Se recogieron $104.000 \mathrm{~kg}$ en las empresas de madera y derivados de Castilla-La Mancha en el año 2002, lo que permitiría valorizar el total de este subproducto en la producción de varias semanas de una industria (de tamaño medio) de elementos cerámicos.

\section{CONCLUSIONS}

The results of this study on the physical and mechanical properties of xiloarcilla during and after specimen firing support the feasibility of re-using wood industry waste such as varnish powder. The entire $104,000 \mathrm{~kg}$ of mixes containing this waste (VP) that were collected in CastillaLa Mancha in 2002 could be re-cycled in a matter of weeks by a (medium-sized) clay product plant. 
Las cantidades de PLB recomendadas para las mezclas con la arcilla, de acuerdo a los resultados de los ensayos físico-mecánicos, no deben de sobrepasar el $2 \%$ del peso total del compuesto. Se recomienda hacer el estudio industrial con el $1 \%$ y $2 \%$ de PLB en la mezcla de arcilla, ya que en mezclas superiores al $2 \%$ decrecen algunas propiedades físico-mecánicas, en especial, los valores de resistencias a flexión y a compresión.

De los ensayos físicos y mecánicos realizados a piezas cerámicas a escala reducida, con la xiloarcilla, se concluye que se puede obtener materiales de construcción de arcilla cocida que presenten mejoras en cuanto a resistencias mecánicas y en cuanto a ligereza.

Los polvos de lijado de los productos barnizados mezclados con polvos de barnizado (PLB) añadidos a la arcilla aportarían un poder calorífico durante la cocción de las pastas de arcilla, que permitirían optimizar el consumo energético de las fábricas productoras de elementos cerámicos para la construcción.

La introducción de PLB, como materia prima en el proceso industrial de fabricación de cerámica sería positiva en cuanto a las emisiones de flúor y cloro inorgánico, puesto que se reducen en un $25 \%$, siendo este tipo de emisiones uno de los problemas medioambientales más importantes en la industria de las cerámicas de construcción.

Los valores obtenidos en los análisis de aguas de los lixiviados del producto xiloarcilla arrojan valores inferiores a los que pudieran considerarse como contaminantes para cerámicas cara vista, lo que permite concluir que es factible la utilización de la mezcla de PLB con arcilla para producción de elementos cerámicos para la construcción.

Para determinar si el proyecto de la mezcla del subproducto PLB a la arcilla, para producir elementos cerámicos de construcción, es o no viable desde el punto de vista medioambiental, es necesario conocer otros datos que están directamente relacionados con la producción industrial, tales como:

- Conocer el consumo neto energético de la instalación industrial.

- Determinar las emisiones de $\mathrm{CO}, \mathrm{CO}_{2}$ y partículas en proceso de combustión del horno.

- Conocer las emisiones de aire del horno en el que se hagan las emisiones.

- Conocer la licencia de emisiones de $\mathrm{CO}_{2}$ de la empresa que utilice este producto.

- Determinar el resto de contaminantes gaseosos emitidos al aire que, según la legislación, hay que seguir en el proceso de producción de cerámicas mediante métodos establecidos por la Ley.
Further to the results of physical and mechanical tests, the recommended amount of VP in clay mixes should not exceed $2 \%$ of the total weight of the compound. An industrial-scale study is recommended with $1 \%$ and $2 \%$ $V P$ in the clay mix, since in mixes with over $2 \%$ certain physical and mechanical properties, particularly flexural and compressive strength, decline.

It may be concluded from the laboratory-scale physical and mechanical tests conducted that xiloarcilla construction materials exhibit higher mechanical strength and are lighter in weight than ordinary fired clay materials.

Wood powder from varnished products mixed with varnish powder (VP) and added to clay would add calorific value to clay pastes during firing that would optimize energy consumption in plants producing clay brick and similar construction products.

The inclusion of VP as a prime material in the industrial manufacture of clay brick and similar would be beneficial in terms of inorganic fluorine and chlorine emissions: such emissions, one of the chief environmental problems facing this industry, are $25 \%$ lower when the clay mix contains VP.

The values obtained in the analysis of the xiloarcilla leachate are under the pollutant thresholds for exposed clay materials; the conclusion, therefore, is that the VP-clay combination constitutes a feasible mix for producing clay brick and similar construction materials.

Other data directly related to industrial production must, however, be gathered to determine whether the manufacture of construction materials from VP and clay mixes is environmentally viable. The information required includes:

- The industrial facility's net energy consumption.

- $\mathrm{CO}, \mathrm{CO}_{2}$ and particle emissions in the combustion process.

- Identification of oven air emissions carrying emissions.

- Type of $\mathrm{CO}_{2}$ emissions licence issued to the company using the product.

- Other gaseous pollutants released into the atmosphere during the production of clay brick and similar products which must be monitored as prescribed by law. 
Es importante, para una siguiente etapa, estudiar y analizar la factibilidad para la producción industrial de componentes a escala real de ladrillos de arcilla cocida con adiciones de PLB (xiloarcilla). Los resultados obtenidos en esta parte experimental del proyecto de investigación "Xiloarcilla 02" permiten avanzar resultados positivos del material.

\section{AGRADECIMIENTOS}

Este artículo es un resumen del Informe final "Xiloarcilla $02 "(1)$, producto del convenio firmado entre la AIMCM Centro Tecnológico de la Madera (CTM) de Toledo y la Consejería de Ciencia y Tecnología de Castilla-La Mancha. El trabajo de investigación de xiloarcilla se desarrolló en la División de Investigación del CTM, con la participación del personal de los laboratorios de este Centro Tecnológico, con la colaboración del Centro Tecnológico de la Arcilla Cocida-AITEMIN, en Toledo, de la Universidad de Castilla-La Mancha, a través del Departamento de Físico-Química de la Facultad de Ciencias Químicas y del Departamento de Construcción y Tecnología Arquitectónicas de la ETS de Arquitectura de la Universidad Politécnica de Madrid.
A subsequent stage should address the feasibility of industrial-scale production of fired clay brick with VP additions (xiloarcilla). According to tresults obtained in this experimental phase of the "Xiloarcilla 02" research project, this material has very promising properties.

\section{ACKNOWLEDGEMENTS}

This article is an abridged version of the final report on Xiloarcilla 02 (1), a research project stemming from an Agreement between the AIMCM - Wood Technology Centre (CTM) of Toledo and the Regional Department of Science and Technology of Castilla-La Mancha. Project research was conducted at the CTM Research Division by the centre's laboratory staff, in conjunction with the University of Castilla-La Mancha's Fired Clay Technology Centre (AITEMIN), in Toledo, through the Physical Chemistry Department of the university's Chemistry Faculty and the Department of Architectural Construction and Technology of the School of Architecture, Polytechnic University of Madrid.

\section{BIBLIOGRAFÍA/ BIBLIOGRAPHY}

(1) Oteiza, I., AIMFCM . CTM: "Informe final Xiloarcilla - Centro Tecnológico de la Madera" (Publicación propia), Toledo, diciembre (2003).

(2) Moslemi, A. A.: "Emerging Technologies in Mineral-BondedWood and Fiber Composites", Advanced Performance Materials, 6 (1999), pp. 161-179.

(3) Criado, E., Regueiro, M., Sánchez, E.: "La industria cerámica en España (1990-2000)", Revista Boletín Sociedad Española Cerámica y Vidrio, 40 (6) (2001), pp. 413-428.

(4) AITEMIN: Informes. Ensayos realizados en los laboratorios, para el proyecto de Xiloarcilla - CTM, publicación propia de AITEMIN, Toledo, 2002.

(5) AIMCM - CTM: Estudio del comportamiento en industrias de la madera y en sus fabricados en materia medio ambiental, publicación propia del CTM, Toledo, 2000.

(6) AIMCM - CTM: Estudio del sector frente a los residuos, Publicación propia del CTM, Toledo, 2002.

(7) AITEMIN. Memoria del proyecto "Optimización del consumo energético por selección de las materias primas", octubre (2000), Toledo.

(8) Acosta, A. y otros: Informe. Ensayos químicos. Proyecto "Xiloarcilla". Compuestos mayoritarios. Análisis de aguas de los lixiviados, Universidad de Castilla-La Mancha, Ciudad Real, 2003.

(9) GAIKER. Informe de ensayos P-03-742. Análisis de humos, Zamudio, 2003.

(10) AFITI LICOF. Informe. Ensayo Determinación del poder calorífico superior PCS del PLB-REA 0025T03, Toledo, 2002.

(11) Cultrone, G.; Torre, M. J. de la, Sebastián, E., Cazalla, O.: "Evaluación de la durabilidad de ladrillos mediante técnicas destructivas

(TD) y no-destructivas (TND)", Mater. Construcc., vol. 53, n. 269 (2003), pp. 41-59.

(12) Baeza, M. T., Acosta, A.: Informe. Comentarios al análisis de humos del proyecto Xiloarcilla. Ciudad Real.

(13) Andreola, F.; Barbieri, L.; Lancelloti, I.; Pozzi, P.: "Reciclado de residuos industriales en la fabricación de ladrillos de construcción. $1^{\text {a }}$ parte". Mater. Construcc., vol. 55, n. 280 (2005), pp. 5-17. 